Sains Malaysiana 50(5)(2021): 1381-1392

http://doi.org/10.17576/jsm-2021-5005-17

\title{
Down Syndrome and Cell Therapy: A Review
}

(Sindrom Down dan Terapi Sel: Suatu Ulasan)

\author{
NorizAm SALAmT, RUSZYMAH HaJi IDRUS \& NOOR WAHIDAH MOHD NASRI*
}

\begin{abstract}
Cell therapy has been considered as an alternative treatment for many diseases, including Down syndrome (DS). However, this treatment remained debatable due to insufficient clinical data. Therefore, this study aims to identify and evaluate studies on the potential of cell therapy in improving the quality of life of DS patients. Relevant English articles and snowball sampling from Science Direct and PubMed (published until August 2019) on the effects of cell therapy on DS was retrieved. Only original articles on the effect of cell therapy in DS patients or Ts65Dn (trisomic) mice were selected. Two independent reviewers reviewed the articles with selective inclusion criteria using a standard data extraction form. Cell therapy showed no significant findings on the physical appearance, cognitive function, social, and behavior skills of DS patients. Interestingly, implantation of murine neural stem cell (mNSC) or murine neural progenitor cell (mNPC) showed better cell survival and response towards brain injury, decrease tau + granules and increase granules density in the dentate gyrus in the trisomic mice. mNSC/mNPC in mice brain was found to be able to migrate to the sites of the injury following chemokine signals and eventually provide neuroprotection and promote axonal growth. To conclude, mNSC/mNPC implantation could be considered as an alternative treatment for DS or DS with early onset of Alzheimer Disease (AD).
\end{abstract}

Keywords: Cell therapy; Down syndrome; sicca cell therapy; trisomy 21

\section{ABSTRAK}

Rawatan terapi sel telah dipertimbangkan sebagai rawatan alternatif pelbagai penyakit, termasuklah Sindrom Down (SD). Walau bagaimanapun, keberkesanan terapi sel masih dibincangkan kerana kekurangan data klinikal. Maka, kami berazam untuk mengenal pasti dan menilai kajian ke atas potensi terapi sel dalam meningkatkan kualiti hidup pesakit SD. Makalah bahasa Inggeris berkaitan dan persampelan snowball atau hand selected daripada Science Direct dan Pubmed (diterbitkan sehingga Ogos 2019) berkaitan kesan terapi sel ke atas SD telah dijalankan. Hanya makalah asal tentang kesan terapi sel pada pesakit SD atau mencit Ts65Dn (trisomi) telah dipilih. Dua orang penilai bebas telah menilai makalah dengan kriteria rangkuman pilihan menggunakan borang pengekstrakan data lazim. Terapi sel menunjukkan keputusan tanpa implikasi terhadap penampilan fizikal, fungsi kognitif dan kemahiran sosial serta tingkah laku pesakit SD. Menariknya, implan sel stem neuron murin (mNSC) atau sel progenitor neuron murin (mNPC) menunjukkan kebolehan sel untuk terus hidup dengan lebih baik dan bertindak balas terhadap kecederaan otak, mengurangkan granul tau+ dan meningkatkan ketumpatan granul di girus dentat pada mencit trisomi. mNSC/mNPC pada otak mencit menunjukkan kebolehan untuk bergerak ke bahagian yang mengalami kecederaan berpandukan isyarat kemokin dan seterusnya melindungi neuron dan menggalakkan pertumbuhan akson. Kesimpulannya, pengimplanan mNSC/mNPC boleh dijadikan sebagai rawatan alternatif untuk pesakit SD atau mengurangkan simptom penyakit Alzhemeir dalam kalangan pesakit SD.

Kata kunci: Sindrom Down; terapi sel; terapi sel sicca; trisomi 21

\section{INTRODUCTION}

Down syndrome (DS), a condition discovered by John Langdon Down, is the most common chromosomal abnormality leading to intellectual disabilities and earlier onset of Alzheimer's disease compared to the general population (Inoue et al. 2019). There are three causes of DS namely: trisomy 21 (95\%), translocation (4\%), and mosaicism (1\%) (National Down Syndrome Society 2019). 
Triplication of chromosome 21, specifically at band 21q22, is associated with characteristic facial and physical appearances, congenital heart defects, reduced immunity, and mild-to-moderate global cognitive impairment (Lott \& Dierssen 2010; Roizen \& Patterson 2003; Zigman et al. 2008). Thus far, there is no single standard treatment for DS. However, advances in medical treatments and interventions, as well as changes in social attitudes, give better life expectancy to DS patients (Glasson et al. 2016). The life expectancy of DS has been shown to greatly increased from 25 years in 1983 to 60 years until now (Caraci et al. 2017). There is also the availability of other alternative therapies, such as drug, physical, antioxidant, gene, and cell therapies that offer positive improvements by reducing the symptoms of DS (National Institute of Neurological Disorder \& Research 2015).

Cell therapy is considered as an alternative treatment for major chronic diseases (Fisher et al. 2016; Lindvall \& Kokaia 2006; Shen et al. 2016). In 2016, there are 417 websites worldwide advertising stem cell treatments directly to the patients whereby 187 of the websites were linked to clinics in the US and 35 were linked to organizations in India (Coghlan 2017). In Malaysia, Xenogenic cells and anti-aging/skincare interventions are offered by most of the clinics (Berger et al. 2016). Gopalan et al. (2017) reported on a controversial stem cell therapy treatment extracted from rabbit for DS patients. However, only stem cell bone marrow and peripheral blood stem cell transplantation for the treatment of haematological disorders such as leukaemia and thalassemia were approved by the Ministry of Health Malaysia (MOHM) (Ministry of Health 2015).

Subcutaneous administration of freeze-dried or lyophilized fetal cells (sicca cell) has been suggested as a treatment for DS (Roizen 2005) as early as the 1950s (Van Dyke 1990). The cells were derived from various organs of fetal cattle, sheep, and rabbit (Roizen 2005; Van Dyke 1990). A claim has been made that sicca cell therapy is able to enhance dysmorphic features of DS and improves intelligence quotient (IQ), motor skills, social behavior, height, language, and memory (Van Dyke et al. 1990).

The mechanism behind the action could be through the migration of the cells into the targeted organs where the injected cells help to revitalize the target organ (Pueschel \& Pueschel 1992). Sicca cell therapy may also increase the IQ of DS children by normalizing the brain volume index with a condition that the therapy started in the early infancy (Pueschel \& Pueschel 1992). The disadvantage of sicca cell therapy is it may induce allergic or hypersensitivity reactions by transmitting the virus between injections and potentiate seizures (Van Dyke et al. 1990). A previous study on a two-month-old DS newborn injected with human embryonic stem cells showed a better understanding, remarkable improvement in limb muscle tone, and increase ability to recognize nearby placed objects after multiple injections (Shroff 2016). These improvements were made possible by the ability of the stem cells to repair and regenerate (Shroff 2016).

Cell therapy treatment remains inconclusive without supporting evidence from randomized, controlled or independent clinical trials. One such example was a report on the alleged use of stem cells that were given through intravenous, intramuscular, and subcutaneous injection to treat 14 DS patients in a clinic in New Delhi, India (Coghlan 2017). The lack of data on the comparison to a similar individual with DS and the route of administration made the findings in this report questionable (Coghlan 2017). Standard treatments and therapies for DS are only recommended after a thorough large, randomized, double-blind research studies that evaluate the safety, efficacy, benefits, risks, and side effects of any treatment given (US National Down Syndrome Society 2019). Therefore, this study aims to identify and evaluate scientifically approved studies on the potential of cell therapy in improving the life quality of DS patients. This review will be able to help those who seek realistic hopes from this kind of treatment for DS patients.

\section{MATERIALS AND METHODS}

\section{LITERATURE REVIEW}

Previous literature review to identify relevant studies focusing on the effects of cell therapy on DS was conducted. A comprehensive search was performed until August 2019 in Science Direct and PubMed databases. The search strategy involved a combination of two keywords namely: 'Down syndrome' AND ‘cell therapy'.

\section{SELECTION OF RESEARCH ARTICLES}

This review only included full articles that were published in the English language that reported the effects of cell therapy on DS in human or animal model. Any other forms of articles including review articles, conference abstracts, supplementary issues, poster presentations, book chapters, short communications, letter to the editor, case reports, news, encyclopaedia, and consensus/ statement/guideline were excluded from this review. 


\section{INCLUSION AND EXCLUSION CRITERIA}

Studies in this review met the following criteria including: articles that showed direct effects of cell therapy on DS in human or animal model, articles that reported an administration of any type of cell in human or animal model with DS, and the participants in human studies were children or adults diagnosed with DS regardless of age. Studies that use a human model with DS but diagnosed with any serious diseases such as cardiovascular disease and leukaemia were excluded.

\section{DATA EXTRACTION AND MANAGEMENT}

The selection of potential articles in this review was conducted in three phases namely: exclusion of any articles with title and keywords that did not meet the inclusion criteria, exclusion of abstract that did not fulfil the inclusion criteria, and selection for the final articles was made after a thorough reading by two independent reviewers. Any conflict in selecting the articles was resolved by analytical discussions between the two independent reviewers in order to reach a mutual agreement. Data extraction table was designed to collect standardized data.
The following information was extracted from the studies such as: author, title and year of the publication; subject and age; methods of the cell therapy intervention; and effect of cell therapy on DS.

\section{SEARCH RESULTS}

The literature search in Science Direct and PubMed databases discovered 107,596 potentially relevant articles. Around 106,918 items were excluded during the first phase as the articles were not associated with DS based on the titles, keywords, and abstracts. Another 308 original study articles were further excluded. A further 66 out of 370 remaining articles were excluded due to the use of non-cell-based therapy such as drug and hormone on the human model presented with chronic diseases. A snowball or hand selected search was carried out and another 3 potential articles were retrieved. A total of 7 articles were included in this review after thorough reading by the reviewers. Any differences of opinion between the reviewers were resolved through discussion. The flow diagram of the different phases of the systematic review is shown in Figure 1.

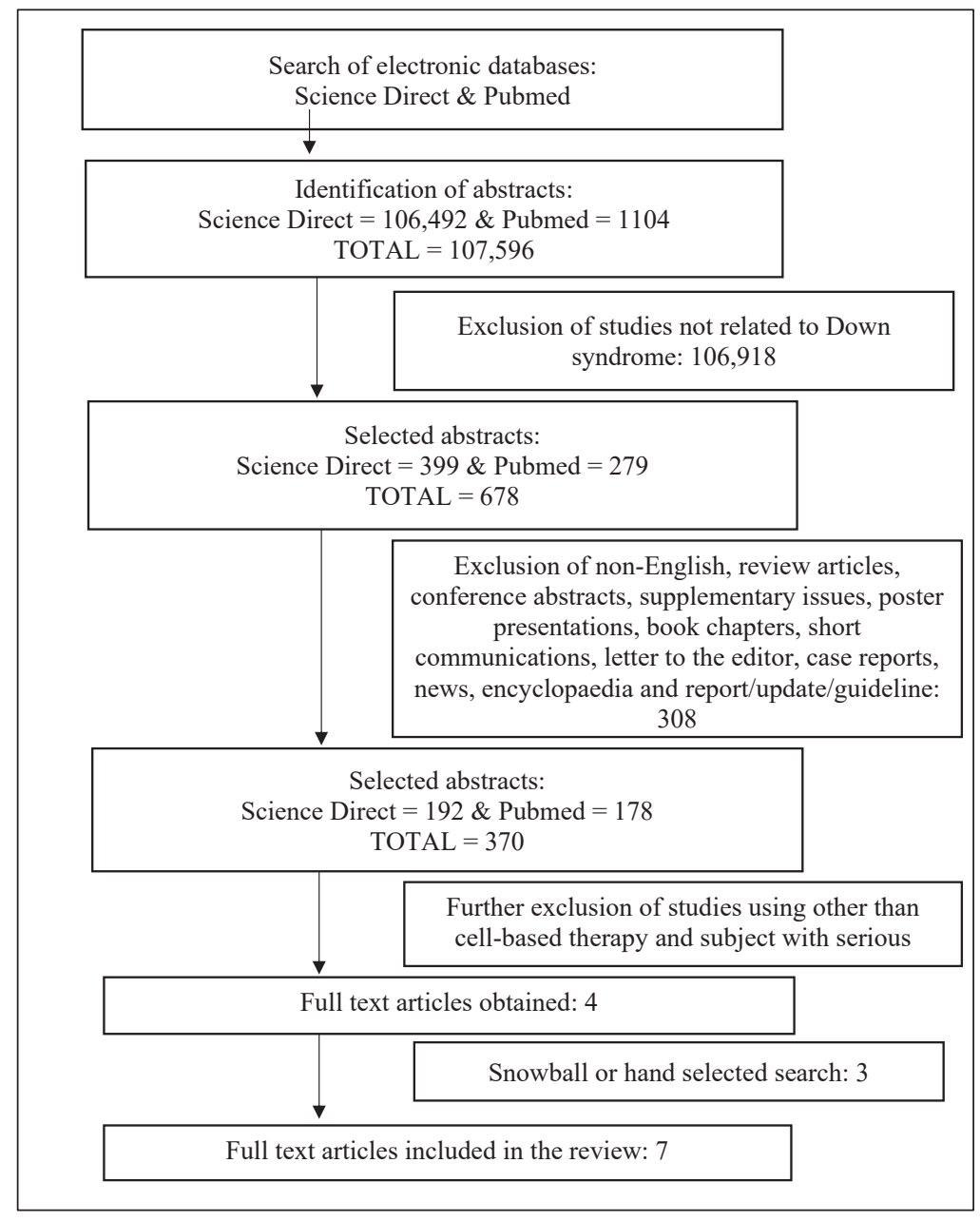

FIGURE 1. Selection article process 


\section{STUDY CHARACTERISTICS}

Table 1 shows the characteristics of the final articles selected that fulfil the inclusion criteria. The recent publication that was used in this review is August 2019. The 7 published articles used in this review used different cell types and route of administration using human or animal models with DS. There were only 4 studies conducted in human reported the age group of the participants (Bardon 1964; Black et al. 1966; Foreman \& Ward 1987; Van Dyke et al. 1990). Furthermore, there were 3 animal studies on Ts65Dn mice with the characteristics of DS were selected (Kern et al. 2011; Rachubinski et al. 2012a, 2012b). In a retrospective study conducted by Van Dyke et al. (1990) on 190 DS participants, only 21 participants received cell therapy some time in their life. In another study, Foreman and Ward (1987) compared 23 DS children with age and sex matched control children.
The participants received cell therapy through injection, however, the specific cell type and route of administration were not highlighted. Sicca cell was used in Bardon (1964) and Black et al. (1966) intervention studies, however, only Black et al. (1966) study reported the route of administration of the injected cells through intramuscular. The animal model studies on Ts65Dn mice used murine Neural Progenitor Cell (mNPC) (Rachubinski et al. 2012a, $2012 b$ ) and murine Neural Stem Cell (mNSC) (Kern et al. 2011). All treated mice were injected with particular cells into the specific region of the hippocampus (Kern et al. 2011; Rachubinski et al. 2012a, 2012b). There were no significant improvements between DS children and normal children reported in all of the human studies. In contrast, all animal models showed promising effects on brain development or neurodegeneration prevention after cell therapy treatment.

TABLE 1. Data extraction table

\begin{tabular}{|c|c|c|c|c|}
\hline Author (year) & Subject (n); age & Method & Result & Conclusion \\
\hline Bardon (1964) & $\begin{array}{l}\text { DS children (10); } \\
\text { not mentioned }\end{array}$ & $\begin{array}{l}\text { Treatment group: } \\
\text { Received } 5 \mathrm{~mL} \text { of } \\
\text { sicca cell injection } \\
\text { Control group: } \\
\text { Did not received any } \\
\text { treatment } \\
\text { Assessment: } \\
\text { 1. Intelligence } \\
\text { (Griffith development } \\
\text { scale) } \\
\text { 2. Motor behaviour }\end{array}$ & $\begin{array}{l}\text { No significant effect even after } 2 \\
\text { years of observation }\end{array}$ & $\begin{array}{l}\text { Sicca cell treatment failed } \\
\text { to demonstrate any effect } \\
\text { on DS }\end{array}$ \\
\hline $\begin{array}{l}\text { Black et al. } \\
(1966)\end{array}$ & $\begin{array}{l}\text { Mentally } \\
\text { retarded children } \\
(59) ; \text { not } \\
\text { mentioned }\end{array}$ & $\begin{array}{l}35 \text { out of } 59 \text { subjects } \\
\text { were children with DS } \\
\text { Treatment group: } \\
\text { Received sicca } \\
\text { cell injections } \\
\text { (intramuscular) three } \\
\text { times for every six } \\
\text { months } \\
\text { Control group: } \\
\text { Received multiple } \\
\text { injections either in } \\
\text { lung, liver, or muscle } \\
\text { for preparation } \\
\text { Assessment: } \\
\text { 1. IQ score } \\
\text { 2. Academic rating, } \\
\text { behavior and sense } \\
\text { training } \\
\text { 3. General health, } \\
\text { coordination, } \\
\text { behaviour, and } \\
\text { awareness }\end{array}$ & $\begin{array}{l}\text { 1. IQ score: } \\
\text { No significant differences between } \\
\text { treatment and control groups } \\
\text { 2. Academic rating, behaviour and } \\
\text { sense training: } \\
\text {-No differences in the distribution } \\
\text { of subjects in treatment and control } \\
\text { groups in their class standings } \\
\text {-Teacher was not able to distinguish } \\
\text { the subject in the treatment or } \\
\text { control group } \\
\text { 3. General health, coordination, } \\
\text { behavior and awareness: } \\
\text { - No significant differences } \\
\text { between treatment and control } \\
\text { groups } \\
\text { - Parents were not able to } \\
\text { distinguish their children was in the } \\
\text { treatment or control group }\end{array}$ & $\begin{array}{l}\text { Sicca cell treatment failed } \\
\text { to demonstrate any effect } \\
\text { on DS and other mentally } \\
\text { retarded children }\end{array}$ \\
\hline
\end{tabular}




\begin{tabular}{|c|c|c|c|c|}
\hline $\begin{array}{l}\text { Foreman \& } \\
\text { Ward (1987) }\end{array}$ & $\begin{array}{l}\text { DS children } \\
(\mathrm{n}=46) ; \text { Boys } \\
-62.6 \text { months } \\
\text { (treated); } 59.1 \\
\text { months (control) } \\
\text { Girls - } 57.4 \\
\text { months (both } \\
\text { groups) }\end{array}$ & $\begin{array}{l}\text { Treatment group: } \\
\text { Received cell therapy } \\
\text { injection for 3-7 days } \\
\text { Control group with } \\
\text { DS: } \\
\text { Answer } \\
\text { questionnaires } \\
\text { Assessment: } \\
\text { 1. General } \\
\text { development, motor } \\
\text { functioning, language } \\
\text { development, and } \\
\text { social development } \\
\text { 2. Height, weight, and } \\
\text { head circumference } \\
\text { 3. Facial appearance } \\
\text { 4. Hair quality } \\
\text { 5. Skin quality }\end{array}$ & $\begin{array}{l}\text { 1. General development: } \\
\text { - no significant difference } \\
\text { between gender } \\
\text { - significant improvement in } \\
\text { performance scale in children } \\
>40 \text { months }(\mathrm{p}<0.05) \\
\text { 2. Physical characteristics: Not } \\
\text { significant } \\
\text { 3. Facial appearance: Not } \\
\text { significant } \\
\text { 4. Hair quality: } \\
\text { - force in grams was significant } \\
\text { (p<0.05) } \\
\text { 5. Skin quality: not significant }\end{array}$ & $\begin{array}{l}\text { Treatment with cell therapy } \\
\text { failed to show significant } \\
\text { effects for children with } \\
\text { Down syndrome }\end{array}$ \\
\hline $\begin{array}{l}\text { Van Dyke et al. } \\
\text { (1990) }\end{array}$ & $\begin{array}{l}\text { DS person } \\
(\mathrm{n}=190) ; \\
\text { 2months }-19.2 \\
\text { years }\end{array}$ & $\begin{array}{l}21 \text { out of } 190 \text { DS } \\
\text { children received one } \\
\text { or more injections } \\
\text { of cell therapy were } \\
\text { matched with persons } \\
\text { with DS who had not } \\
\text { received cell therapy } \\
\text { (retrospective study) } \\
\text { Type of cell: Sicca } \\
\text { cell } \\
\text { Assessment: } \\
\text { 1. Growth } \\
\text { 2. Social adaptive } \\
\text { 3. Motor } \\
\text { Development } \\
\text { 4. Cognitive } \\
\text { Development }\end{array}$ & $\begin{array}{l}\text { 1. Growth: Not significant } \\
\text { 2. Social adaptive: Not significant } \\
\text { 3. Motor Development: Not } \\
\text { significant } \\
\text { 4. Cognitive Development: Not } \\
\text { significant }\end{array}$ & $\begin{array}{l}\text { This retrospective study } \\
\text { showed no statistically } \\
\text { significant differences for } \\
\text { any } 18 \text { social development } \\
\text { or growth variables } \\
\text { measured }\end{array}$ \\
\hline $\begin{array}{l}\text { Rachubinski et } \\
\text { al. }(2012 a)\end{array}$ & $\begin{array}{l}\text { Ts65Dn mouse } \\
\text { pups }\end{array}$ & $\begin{array}{l}\text { Type of animal: } \\
\text { Ts65Dn mouse } \\
\text { Cell Line: C17.2 } \\
\text { murine Neural } \\
\text { Progenitor Cell } \\
\text { Dosage: 100,000 } \\
\text { undifferentiated } \\
\text { C17.2-GFP mNPC (1 } \\
\mu L) \text { (treatment group) } \\
\text { or with } 1 \mu \mathrm{L} \text { sterile } \\
0.09 \% \text { saline (control } \\
\text { group) } \\
\text { Location of implant: } \\
\text { Injections in the } \\
\text { dorsal hippocampus } \\
\text { (+2 mm AP, } 61 \text { mm } \\
\text { LM, } 22.5 \text { mm DV } \\
\text { from lambda) }\end{array}$ & $\begin{array}{l}\text { 1. Weights and developmental } \\
\text { milestones: } \\
\text { - no significant effect on the } \\
\text { weight gain } \\
\text { 2. Survival of the mNPC in the host } \\
\text { brain: } \\
\text { - trisomic brains have better cell } \\
\text { survival in the hippocampus than } \\
\text { disomic brains (p<0.0001) } \\
\text { 3. Quantification of granule cell } \\
\text { density in DG: } \\
\text { - implantation of mNPC } \\
\text { significantly increases the density } \\
\text { of granule cells by } 33 \% \text { compared } \\
\text { to the non-treated group (p<0.05) } \\
4 . \text { Neuroimmune response to } \\
\text { implantation: } \\
\text { - no long-term immunoreactivity } \\
\text { was detected } 16 \text { weeks after } \\
\text { implantation }\end{array}$ & $\begin{array}{l}\text { The implantation of mNPC } \\
\text { resulted in a significant } \\
\text { increase in the density of } \\
\text { dentate granule cells but did } \\
\text { not elicit cognitive changes } \\
\text { in the trisomic mice either } \\
\text { neonatally or adulthood }\end{array}$ \\
\hline
\end{tabular}




\begin{tabular}{|c|c|c|c|c|}
\hline & & $\begin{array}{l}\text { Assessment: } \\
\text { 1. Baseline weights } \\
\text { 2. Survival of the } \\
\text { mNPC in the host } \\
\text { brain } \\
\text { 3. Quantification of } \\
\text { granule cells of the } \\
\text { dentate gyrus } \\
\text { 4. Quantification } \\
\text { of the number of } \\
\text { neurons per mm }{ }^{2} \text { area } \\
\text { 5. Behavior Testing } \\
\text { (Neonatal) - righting } \\
\text { response, cliff } \\
\text { avoidance behavior, } \\
\text { negative geotaxis } \\
\text { response, and eye and } \\
\text { ear opening } \\
6 . \text { Behavior Testing } \\
\text { (Adult) - Plus Maze, } \\
\text { Morris Water Maze, } \\
\text { and Novel Object } \\
\text { Recognition (NOR) } \\
\text { and Conditioned } \\
\text { Taste Avoidance. } \\
\text { (CTA) }\end{array}$ & $\begin{array}{l}\text { 5. Behavioral Testing Methods } \\
\text { (Neonatal): } \\
\text {-Righting response: not significant } \\
\text {-Cliff avoidance: not significant } \\
\text {-Negative geotaxis: treatment with } \\
\text { mNPC delayed the development } \\
\text { of the disomic group to a level } \\
\text { comparable to trisomic group } \\
\text { (p<0.05). No significant differences } \\
\text { between the implanted and } \\
\text { untreated trisomic group } \\
\text {-Eye and ear opening: not } \\
\text { significant } \\
\text { Treatment with mNPC produced a } \\
\text { delay of } 11.0 \text { hours in ear opening } \\
\text { in disomic mice compared to } \\
\text { untreated trisomic mice (p<0.05) } \\
\text { 6. Behavior Testing Methods } \\
\text { (Adult): } \\
\text {-Plus maze: Treatment with } \\
\text { mNPC significantly improve the } \\
\text { performance in trisomic mice } \\
\text { (p<0.05) } \\
\text {-Morris water maze: not significant } \\
\text {-CTA: not significant } \\
\text {-NOR: not significant }\end{array}$ & \\
\hline $\begin{array}{l}\text { Rachubinski et } \\
\text { al. (2012b) }\end{array}$ & $\begin{array}{l}\text { Ts65Dn aged } \\
\text { mouse }(11- \\
12 \mathrm{mo})\end{array}$ & $\begin{array}{l}\text { Type of animal: } \\
\text { retired female } \\
\text { breeders from the } \\
\text { Ts65Dn colony, } \\
\text { which had been } \\
\text { implanted on PND2 } \\
\text { Cell Line: C17.2 } \\
\text { murine Neural } \\
\text { Progenitor Cell } \\
\text { Dosage: } 100,000 \\
\text { undifferentiated } \\
\text { C17.2-GFP mNPC (1 } \\
\mu \mathrm{L}) \text { (treatment group) } \\
\text { or with } 1 \mu \mathrm{L} \text { sterile } \\
0.09 \% \text { saline (control } \\
\text { group) } \\
\text { Location of implant: } \\
\text { Injections in the } \\
\text { dorsal hippocampus } \\
\text { (+2 mm AP, } 61 \text { mm } \\
\text { LM, } 22.5 \text { mm DV } \\
\text { from lambda). }\end{array}$ & $\begin{array}{l}\text { 2. Hippocampal neuroanatomy: } \\
\text {-more NPC was found in the } \\
\text { trisomic brains than in the disomic } \\
\text { brains ( }<<0.05 \text { ) but no difference } \\
\text { between the saline implanted and } \\
\text { the NPC implanted brains } \\
\text {-unimplanted brains had } \\
\text { significantly more neurons than } \\
\text { either saline or NPC implanted } \\
\text { brains ( }<0.05 \text { ) } \\
\text {-Implanted brains were } \\
\text { significantly reduced in the number } \\
\text { of granule cells compared to } \\
\text { unimplanted brains ( }<<0.05 \text { ) but } \\
\text { no difference between the saline } \\
\text { implanted and the NPC implanted } \\
\text { brains } \\
\text {-saline-treated brains have higher } \\
\text { tau+ granule counts than all groups, } \\
\text { while NPC implanted } \\
\text { brains more closely resembled the } \\
\text { untreated brains }\end{array}$ & $\begin{array}{l}\text { Implantation during } \\
\text { neonatal increase the } \\
\text { survival of the NPC in the } \\
\text { brain of the trisomic mice. } \\
\text { However, it showed modest } \\
\text { cognitive improvements and } \\
\text { reduced tau+ accumulations } \\
\text { and these might be due to } \\
\text { more potent effects of the } \\
\text { implantation procedure }\end{array}$ \\
\hline
\end{tabular}




\begin{tabular}{|c|c|c|c|c|}
\hline $\begin{array}{l}\text { Kern et al. } \\
(2011)\end{array}$ & $\begin{array}{l}\text { Ts65Dn aged } \\
\text { mouse }(12 \mathrm{mo})\end{array}$ & $\begin{array}{l}\text { Cell Line: C17.2 } \\
\text { murine Neural Stem } \\
\text { Cell (mNSC) } \\
\text { Dosage: } 500,000 \\
\text { viable disomic } \\
\text { mNSCs ( } 1 \mu \mathrm{L} \text { ) } \\
\text { (treatment group) } \\
\text { or with } 4 \mu \mathrm{L} \text { sterile } \\
\text { saline (control group) } \\
\text { Location of implant: } \\
\text { Injections in the } \\
\text { hippocampus (-2.0 } \\
\text { mm AP, -2.0 mm ML, } \\
1.5 \text { mm DV relative to } \\
\text { bregma) } \\
\text { Assessment: } \\
1 . \text { Quantification of } \\
\text { protein accumulations } \\
\text { in the hippocampus: } \\
\text { the three layers of } \\
\text { CA } 1 \text { and CA3 (Rad/ } \\
\text { LM, the pyramidal } \\
\text { cell layer, and stratum } \\
\text { oriens), and the } \\
\text { dentate gyrus (DG) }\end{array}$ & $\begin{array}{l}\text {-Clusters of granulated protein } \\
\text { accumulation was found in both } \\
\text { aged ( } 13 \text { months) disomic and } \\
\text { trisomic Ts65Dn mice } \\
\text {-Extrasomatic granules were } \\
\text { located primarily in the } \\
\text { hippocampus and olfactory bulb } \\
\text {-Granules in the aged trisomic and } \\
\text { disomic Ts65Dn mice appear to } \\
\text { be similar in size, appearance, and } \\
\text { location as granules described in } \\
\text { aged C57BL/6 mice and murine AD } \\
\text { models. } \\
\text {-No A } \beta \text { plaque deposition in the } \\
\text { brains of the aged Ts65Dn mice } \\
\text {-A strong tau and less strong reelin } \\
\text { detected in the granules found in } \\
\text { the disomic and trisomic Ts65Dn } \\
\text { brain } \\
\text {-Extracellular clusters in the } \\
\text { disomic and trisomic brains were } \\
\text { positive for reelin } \\
\text {-Trisomic mice had three times } \\
\text { the number of tau/reelin-positive } \\
\text { granules as disomic mice and the } \\
\text { majority of hippocampal tau/reelin- } \\
\text { positive clustered granules were } \\
\text { located in Rad/LM of CA } 1 \text { in the } \\
\text { hippocampus }\end{array}$ & $\begin{array}{l}\text { NSC implantation reduces } \\
\text { tau/reelin accumulation in } \\
\text { the aging DS and AD. These } \\
\text { changes can be used as an } \\
\text { index for neuropathological } \\
\text { assessment in aging DS and } \\
\text { AD }\end{array}$ \\
\hline
\end{tabular}

\section{RESULTS AND DISCUSSION}

\section{HUMAN STUDY}

In this review, 4 studies were conducted on human with DS between the year of 1964 and 1990. All studies showed irrelevant effectiveness of cell therapy in improving the quality of life of DS. Only 3 studies showed the use of sicca cell as the injected cell type (Bardon et al. 1964; Black et al. 1966; Van Dyke et al. 1990) whereas Foreman and Ward (1987) study has no report on the type of cell used. All study reported injection as the main route of administration, however, only 1 study specifically mentioned the intramuscular as the specific site of injection (Black et al. 1966). The frequency of injection was also different in each study with: one or more injection (Van
Dyke et al. 1990), between 3-7 injections with 6-12 months apart (Foreman \& Ward 1987), and 3 series of administration approximately 6 months apart (Black et al. 1966). Only 1 study with no reports on the numbers of injections given to the subject (Bardon et al. 1964). The parameters measured include physical appearance, cognitive, behavior, and skills development (Table 2). There were no significant effects of cell therapy treatments observed on the participants with DS, which could be due to several reasons including: no specific type of cell, no specific dose or volume of the injected cell, and non-suitable route of cell administration. The main flaw in all of the human studies was no discussion on the characteristics of the injected cells used in the studies (Bardon et al. 1964; Black et al. 1966; Foreman \& Ward 1987; Van Dyke et al. 1990). 
TABLE 2. Parameters measured in the DS patients after cell injection

\begin{tabular}{ll}
\hline Type of parameter & \multicolumn{1}{c}{ Details } \\
\hline Physical appearance & $\begin{array}{l}\text { Height, weight, head circumference, middle arm circumference, arm muscle circumference, } \\
\text { subscapular skinfold, triceps skinfold, facial appearance, hair quality, skin quality }\end{array}$ \\
Cognitive & IQ score, academic rating, mental development \\
Behavior & Social, adaptive behavior composite \\
Skills & Motor, language, daily living \\
\hline
\end{tabular}

\section{ANIMAL STUDY}

The 3 studies on animal models used in this review evaluate the effectiveness of cell therapy on Ts65Dn mice. Ts65Dn was the most common strain of mice used in the DS model with 426 entries in PubMed until August 2019 (PubMed 2019). This mouse model carries T(17;16) translocation that resulted in two-thirds of the human chromosome 21 homologue in its chromosome 16 segment (Reinholdt et al. 2011). Chromosome 16 of the Ts65Dn mice is orthologous to $67 \%$ of human chromosome 21 that mimics the physical and cognitive phenotypes of a DS human being. Thus, Ts65Dn becomes the most suitable model for drug development with the aim of improving behavioral and cognitive function of DS (Smith et al. 2014). Several studies reported the use of older Ts65Dn mice (11-12 months old (Kern et al. 2011; Rachubinski et al. 2012b) or mice pups (Rachubinski et al. 2012a) as their subjects. Rachubinski et al. (2012b) study reported the effect of implanted $\mathrm{mNPC}$ on retired female breeders from the Ts65Dn colony while mNSC was used in Kern et al. (2011) study. Rachubinski et al. (2012a) also showed a similar mNPC resident population of microglia and astrocytes and absence of glial scarring between the implanted and unimplanted mice indicating no long-term immunoreactivity up to 16 weeks post implantation. In addition, Patil (2018) reported the use of neural stem and progenitor cells to compensate and replace the defective cells in chronic diseases. Similar findings showed NSC/ NPC transplantation in the brain was successfully migrated to the damage sites and significantly improves injury-induced spatial learning deficits. The reduction of astroglial activation and microglial/macrophage was observed while enhancing the mobilization of endogenous oligodendrocyte precursor cells (Koutsoudaki et al. 2016). Therefore, due to these characteristics, NSC was postulated as the potential treatment for DS or DS with the early onset of AD. DS is usually presented with increase amyloid- $\beta(A \beta)$ deposition, which is believed to be related to the triplication and lifelong overproduction of amyloid precursor protein (APP) gene (a gene located at chromosome 21) (Wiseman et al. 2015; Zis \& Strydom 2018).

Implantation of mNPC in Ts65Dn mice showed trisomic mice have a better proportion of cell survival in the hippocampus compared to the disomic mice after four months post-implantation (Rachubinski et al. 2012a). Implanted cells were often subjected to collateral damage and death due to the wound healing process induced by the transplant procedure. Therefore, it was possible that these detrimental effects were lessened in the trisomic brain to allow higher chances of survival (Bjugstad et al. 2008; Bosch et al. 2004; Ebert et al. 2010; Jing et al. 2009; Kazma et al. 2010). In addition, mNPC were abundant at the site of injection indicating that hippocampus of trisomic mice was compromised but was not enough to affect the cognition ability (Rachubinski et al. 2012a). In aging trisomic mice, majority of the MNPC migrated away from the hippocampus towards the subventricular zone (SVZ) (Rachubinski et al. 2012b).

The migration of mNPC towards SVZ appears to be age-related as cell identification in both studies were conducted at a different period, which was at 4- and 12-months post-implantation and there was no difference in the migration pattern for trisomic and disomic mice (Rachubinski et al. 2012a, 2012b). During aging process, $\mathrm{mNPC}$ in SVZ and the subgranular zone (SGV) shift to a quiescent state. However, the SGV of mNPC can be reactivated through exercise and nutrient enrichment whereas the mNPC of the SVZ remain quiescent (Bouab et al. 2011; Chakrabarti et al. 2011; Lugert et al. 2010; 
Yang et al. 2011). The reactivation of mNPC in SGV may signify neurogenesis in which the new granule cells grow inside the dendrites into a molecular layer hence extending the axons into the CA3 region. This axonal outgrowth is facilitated by the tau protein (Fuster-Matanzo et al. 2012). Tau is a protein that modulates the stability of axonal microtubules and is also associated with intracellular neurofibrillary tangles (NFT). Reelin is an extracellular glycoprotein important for laminar structuring in the brain, for synaptic plasticity, and for modulating tau phosphorylation (Deustch et al. 2006; Frotscher 1997; Niu et al. 2008). Disrupted reelin signaling was associated with increased tau phosphorylation, which will progressively disrupt the neuronal cytoskeleton and displaced by the appearance of NFT (Bloom et al. 2014). The presence of $\mathrm{A} \beta$ plaques and NFT marked the onset of $\mathrm{AD}$ in $\mathrm{DS}$ at the age of 40 years old (Leverenz \& Raskind 1998). It is estimated that at the age of 60 years old, two-third of DS experienced clinical dementia (Mccarron et al. 2014). Tau/reelin-positive granules most likely represent a degenerative event whereby the core contains cellular debris from the cell loss surrounded by the evidence of ongoing neurodegeneration. Both studies by Kern et al. (2011) and Rachubinski et al. (2012b) reported that more tau-positive granules were found in aging trisomic mice compared to the aging disomic mice. After a month of NSC implantation, aging trisomic and disomic mice showed a reduced number of tau/reelin-positive granules. This suggests that NSC might regulate tau phosphorylation and facilitate healthy neuron by producing growth factors (Elliott et al. 2006; Kamie et al. 2007; Niles et al. 2004). Therefore, the decrease in growth factor synthesis was a prominent characteristic in $\mathrm{DS}, \mathrm{AD}$, and normal aging (Pallas et al. 2008; Tomobe \& Nomura 2009).

DS was also associated with hypocellularity in the dentate gyrus (DG) due to reduced cell proliferation and increased apoptosis (Lopez-Hidalgo et al. 2016; Lorenzi $\&$ Reeves 2006). Although there were no differences in the granule cell density between trisomic and disomic mice, the density of the granule cells was significantly increased after implantation with NPC compared to the untreated mice (Rachubinski et al. 2012a). This condition resulted from the significant decrease of the granule cells diameter in the NPC implanted brain as indicated by reduced space between the cells and a column-like assembly structure (Rachubinski et al. 2012a). The implantation of NPC was speculated to have an indirect effect by facilitating the environment that promotes endogenous DG neurogenesis (Insausti et al. 1998), thus, benefitting the aged Ts65Dn mice that have fewer neurons in DG (Hattiangady et al. 2007). Surprisingly, significant differences in the hypocellularity in DG was not observed in 12 months postimplanted NPC brains between trisomic and disomic mice (Rachubinski et al. 2012b) although some studies showed fewer neurons in Ts65Dn mice (Llorens-Martin et al. 2010; Lorenzi \& Reeves 2006; Shichiri et al. 2011). This may be due to the enrichment during the early life whereby NPC was implanted two days after birth (PND2) and mice were handled daily in order to measure their developmental milestone achievement (Rachubinski et al. 2012a). Postnatal stimulation also demonstrated neurogenesis in DG in wild-type and Ts65Dn mice (Chakrabarti et al. 2011; Lemaire et al. 2006).

Ts65Dn mice were implanted with NPC two days after birth (PND2) and the cognitive function was assessed by Rachubinski et al. (2012a). The study showed that achievement of motor skills, specifically righting response, cliff avoidance and negative geotaxis was seen between 5-10 days after birth, whereas eye and ear opening emerged between PND11-13 (Rachubinski et al. 2012a). No significant body weight changes among disomic and trisomic mice pups were observed either in treated or control groups (Rachubinski et al. 2012a). No significant effects on all cognitive function tested in neonatal mice that were treated with mNPC (Rachubinski et al. 2012a) due to low numbers of surviving $\mathrm{mNPC}$ in the brain. In contrast, implantation of mNPC only improved conditioned taste avoidance (CTA) in the trisomic aging mice (Rachubinski et al. 2012b). Surprisingly, saline implantation in the disomic mice resulted in a detrimental effect on the mice's cognitive performance in both CTA and Novel Object Recognition task (NOR). Moreover, this study also showed a different wound healing/neuroimmune response towards brain injury in disomic and trisomic mice after implantation procedure (Rachubinski et al. 2012b). The overexpression of superoxide dismutase 1 (SOD1), a triplicated gene in both human and Ts65Dn mice, may provide additional protection for trisomic mice from reactive oxygen species (ROS) generated during injury (Dimayuga et al. 2007; Sebastiá et al. 2004). Increase release of growth factors during injury allows more repair to the trisomic brain compared to the normal condition (Bianchi et al. 2010; Bimonte-Nelson et al. 2003). Injury induced excitotoxicity from free glutamate might be unharmful due to reduced glutamate-receptor activity in the trisomic mice (Belichenko et al. 2009; Costa \& Grybko 2005; Kleschevnikov et al. 2004). 


\section{CONCLUSION}

In this review, cell therapy was unable to show its effectiveness in improving physical appearance, cognitive, behavior, and skills development in DS patient. These might be due to the incomprehensive information on the type of cell implanted, the right dosage, and route of administration reported in these studies. In contrast, animal models exhibited a promising outcome with an administration of NSC/NPC into the hippocampus of Ts65Dn mice was able to improve cognitive function and symptoms of $\mathrm{AD}$ in the trisomic mice. Furthermore, the application of NSC/NPC in DS patient could be limited by: the invasive therapy as the cells need to be injected directly into the brain for maximum efficacy, the effects were limited to the implantation site and close areas, the effects may be short-lived, and the potential risk of injury due to implantation process. In addition, public awareness is necessary on the possible risk of injecting cell into the body as any unproven treatment without solid and sound evidence might be harmful and a waste of money. Cell therapy is considered as one of the potential therapies in DS, however, more studies are needed to provide sufficient data on the safety and efficacy on its effectiveness on patients with DS.

\section{REFERENCES}

Bardon, L.M. 1964. Sicca cell treatment in mongolism. Lancet 2(7353): 234-235.

Belichenko, P.V., Kleschevnikov, A.M., Masliah, E., Wu, C., Takimoto-Kimura, R., Salehi, A. \& Mobley, W.C. 2009. Excitatory-inhibitory relationship in the fascia dentata in the ts $65 \mathrm{dn}$ mouse model of down syndrome. Journal of Comparative Neurology 512(4): 453-466.

Berger, I., Ahmad, A., Bansal, A., Kapoor, T., Sipp, D. \& Rasko, J.E.J. 2016. Global distribution of businesses marketing stem cell-based interventions. Cell Stem Cell 19(2): 158-162.

Bianchi, P., Ciani, E., Guidi, S., Trazzi, S., Felice, D. \& Grossi, G. 2010. Early pharmacotherapy restores neurogenesis and cognitive performance in the ts65dn mouse model for down syndrome. Journal of Neuroscience 30(26): 8769-8779.

Bimonte-Nelson, H.A., Hunter, C.L., Nelson, M.E. \& Granholm, A.C. 2003. Frontal cortex BDNF levels correlate with working memory in an animal model of down syndrome. Behavioral Brain Research 139(1-2): 47-57.

Bjugstad, K.B., Teng, Y.D., Redmond, Jr. D.E., Elsworth, J.D., Roth, R.H. \& Cornelius, S.K. 2008. Human neural stem cells migrate along the nigrostriatal pathway in a primate model of Parkinson's disease. Experimental Neurology 211(2): 362-369.

Black, D.B., Kato, J.G. \& Walker, G.W.H. 1966. A study of improvement in mentally retarded children accruing from sicca cell therapy. American Journal of Mental Deficiency 70(4): 499-508.
Bloom, G.S. 2014. Amyloid- $\beta$ and tau: The trigger and bullet in Alzheimer disease pathogenesis. JAMA Neurology 71(4): 505-508.

Bouab, M., Paliouras, G.N., Aumont, A., Forest-Berard, K. \& Fernandes, K.J. 2011. Aging of the subventricular zone neural stem cell niche: Evidence for quiescence-associated changes between early and mid-adulthood. Neuroscience 173: 135-149.

Bosch, M., Pineda, J.R., Sunol, C., Petriz, J., Cattaneo, E. \& Alberch, J. 2004. Induction of gabaergic phenotype in a neural stem cell line for transplantation in an excitotoxic model of Huntington's disease. Experimental Neurology 190(1): 42-58.

Caraci, F., Iulita, M.F., Pentz, R., Aguilar, L.F., Orciani, C. \& Barone, C. 2017. Searching for new pharmacological targets for the treatment of Alzheimer's disease in down syndrome. European Journal of Pharmacology 817: 7-19.

Chakrabarti, L., Scafidi, J., Gallo, V. \& Haydar, T.F. 2011. Environmental enrichment rescues postnatal neurogenesis defect in the male and female ts $65 \mathrm{dn}$ mouse model of down syndrome. Developmental Neuroscience 33(5): 428441.

Coghlan, A. 2017. Clinic Claims Stem Cells Treat Down's Syndrome. New Scientist. Accessed on 1 February 2017.

Costa, A.C. \& Grybko, M.J. 2005. Deficits in hippocampal CA1 LTP induced by TBS but not HFS in the Ts65Dn mouse: A model of down syndrome. Neuroscience Letter 382(3): 317-322.

Deutsch, S.I., Rosse, R.B. \& Lakshman, R.M. 2006. Dysregulation of tau phosphorylation is a hypothesized point of convergence in the pathogenesis of Alzheimer's disease, frontotemporal dementia and schizophrenia with therapeutic implications. Progress in Neuro-Psychopharmacology \& Biological Psychiatry 30(8): 1369-1380.

Dimayuga, F.O., Wang, C., Clar, J.M., Dimayuga, E.R., Dimayuga, V.M. \& Bruce-Keller, A.J. 2007. SOD1 overexpression alters ROS production and reduces neurotoxic inflammatory signaling in microglial cells. Journal of Neuroimmunology 182(1-2): 89-99.

Ebert, A.D., Barber, A.E., Heins, B.M. \& Svendsen, C.N. 2010. Ex vivo delivery of GDNF maintains motor function and prevents neuronal loss in a transgenic mouse model of Huntington's disease. Experimental Neurology 224(1): 155-162.

Elliott, E. \& Ginzburg, I. 2006. The role of neurotrophins and insulin on tau pathology in Alzheimer's disease. Reviews in the Neurosciences 17(6): 635-642.

Fisher, S.A., Doree, C., Mathur, A., Taggart, D.P. \& MartinRendon, E. 2016. Stem cell therapy for chronic ischemic heart disease and congestive heart failure. Cochrane Database of Systematic Reviews (12): CD007888.

Foreman, P.J. \& Ward, J. 1987. An evaluation of cell therapy in down syndrome. Journal of Paediatrics and Child Health 23(3): 151-156 
Frotscher, M. 1997. Dual role of Cajal-Retzius cells and reelin in cortical development. Cell and Tissue Research 290(2): 315-322.

Fuster-Matanzo, A., Llorens-Martín, M., Jurado-Arjona, J., Avila, J. \& Hernández, F. 2012. Tau protein and adult hippocampal neurogenesis. Frontiers in Neuroscience 6: 1-6.

Glasson, E.J., Jacques, A., Wong, K., Bourke, J. \& Leonard, H. 2016. Improved survival in down syndrome over the last 60 years and the impact of perinatal factors in recent decades. The Journal of Pediatrics 169: 214-220.

Gopalan, N., Mohd Noor, S.N. \& Mohamed, M.S. 2017. Guidelines, policies, laws? how best to address the ethics of stem cell research in Malaysia. e-Proceeding of the 5th International Conference on Social Sciences Research. pp. 52-69.

Hattiangady, B., Shuai, B., Cai, J., Coksaygan, T., Rao, M.S. \& Shetty, A.K. 2007. Increased dentate neurogenesis after grafting of glial restricted progenitors or neural stem cells in the aging hippocampus. Stem Cells 25(8): 2104-2117.

Inoue, M., Kajiwara, K., Yamaguchi, A., Kiyono, T., Samura, O. \& Akutsu, H. 2019. Autonomous trisomic rescue of down syndrome cells. Laboratory Investigation 99(6): 885-897.

Insausti, A.M., Megias, M., Crespo, D., Cruz-Orive, L.M., Dierssen, M. \& Vallina, T.F. 1998. Hippocampal volume and neuronal number in ts $65 \mathrm{dn}$ mice: A murine model of down syndrome. Neuroscience Letter 253(3): 175-178.

Jing, M., Shingo, T., Yasuhara, T., Kondo, A., Morimoto, T. \& Wang, F. 2009. The combined therapy of intrahippocampal transplantation of adult neural stem cells and intraventricular erythropoietin-infusion ameliorates spontaneous recurrent seizures by suppression of abnormal mossy fiber sprouting. Brain Research 1295: 203-217.

Kamei, N., Tanaka, N., Oishi, Y., Hamasaki, T., Nakanishi, K. \& Sakai, N. 2007. BDNF, NT-3, and NGF released from transplanted neural progenitor cells promote corticospinal axon growth in organotypic cocultures. Spine 32(12): 12721278.

Kazma, M., Izrael, M., Revel, M., Chebath, J. \& Yanai, J. 2010. Survival, differentiation, and reversal of heroin neurobehavioral teratogenicity in mice by transplanted neural stem cells derived from embryonic stem cells. Journal of Neuroscience Research 88(2): 315-323.

Kern, D.S., Maclean, K.N., Jiang, H., Synder, E.Y., Sladek, Jr. J.R. \& Bjugstad, K.B. 2011. Neural stem cells reduce hippocampal tau and reelin accumulation in aged ts $65 \mathrm{dn}$ down syndrome mice. Cell Transplant 20(3): 371-379.

Kleschevnikov, A.M., Belichenko, P.V., Villar, A.J., Epstein, C.J., Malenka, R.C. \& Mobley, W.C. 2004. Hippocampal long-term potentiation suppressed by increased inhibition in the Ts65Dn mouse, a genetic model of down syndrome. Journal of Neuroscience 24(37): 8153-8160.

Koutsoudaki, P.N., Papastefanaki, F., Stamatakis, A., Kouroupi, G., Xingi, E. \& Stylianopoulou, F. 2016. Neural stem/ progenitor cells differentiate into oligodendrocytes, reduce inflammation, and ameliorate learning deficits after transplantation in a mouse model of traumatic brain injury. GLIA 64(5): 763-779.

Lemaire, V., Lamarque, S., Le Moal, M., Piazza, P.V. \& Abrous, D.N. 2006. Postnatal stimulation of the pups counteracts prenatal stress-induced deficits in hippocampal neurogenesis. Biological Psychiatry 59(9): 786-792.

Leverenz, J.B. \& Raskind, M.A. 1998. Early amyloid deposition in the medial temporal lobe of young down syndrome patients: A regional quantitative analysis. Experimental Neurology 150(2): 296-304.

Lindvall, O. \& Kokaia, Z. 2006. Stem cells for the treatment of neurological disorders. Nature 441(7097): 1094-1096.

Llorens-Martin, M.V., Rueda, N., Tejeda, G.S., Florez, J., Trejo, J.L. \& Martinez-Cue, C. 2010. Effects of voluntary physical exercise on adult hippocampal neurogenesis and behavior of ts $65 \mathrm{dn}$ mice, a model of down syndrome. Neuroscience 171(4): 1228-1240.

López-Hidalgo, R., Ballestín, R., Vega1, J., Blasco-Ibáñez, J.M., Crespo, C. \& Gilabert-Juan, J. 2016. Hypocellularity in the murine model for down syndrome ts $65 \mathrm{dn}$ is not affected by adult neurogenesis. Frontiers in Nueroscience 10(75): 1-13.

Lorenzi, H.A. \& Reeves, R.H. 2006. Hippocampal hypocellularity in the ts $65 \mathrm{dn}$ mouse originates early in development. Brain Research 1104(1): 153-159.

Lott, I.T. \& Dierssen, M. 2010. Cognitive deficits and associated neurological complications in individuals with down's syndrome. Lancet Neurology 9(6): 623-633.

Lugert, S., Basak, O., Knuckles, P., Haussler, U., Fabel, K. \& Gotz, M. 2010. Quiescent and active hippocampal neural stem cells with distinct morphologies respond selectively to physiological and pathological stimuli and aging. Cell Stem Cell 6(5): 445-456.

Mccarron, M., Mccallion, P., Reilly, E. \& Mulryan, N. 2014. A prospective 14-year longitudinal follow-up of dementia in persons with down syndrome. Journal of Intellectual Disability Research 58(1): 61-70.

Ministry of Health Malaysia. 2015. Guidance Document and Guidelines for Registration of Cell and Gene Therapy Products (CGTPS) In Malaysia. National Down Syndrome Society: About Down Syndrome. https://www.ndss.org/ about-down-syndrome/down-syndrome/ Accessed on 15 July 2019.

National Institute of Neurological Disorder \& Research Multiple Sclerosis. 2019. Hope through Research. http:// www.ninds.nih.gov/disorders/multiple_sclerosis/detail multiple_sclerosis.htm. Accessed on 19 July 2019.

Niles, L.P., Armstrong, K.J., Rinco'n Castro, L.M., Dao, C.V., Sharma, R., McMillan, C.R., Doering, L.C. \& Kirkham, D.L. 2004. Neural stem cells express melatonin receptors and neurotrophic factors: Colocalization of the MT1 receptor with neuronal and glial markers. BMC Neuroscience 5: 41-49. 
Niu, S., Yabut, O. \& D'Arcangelo, G.J. 2008. The reelin signaling pathway promotes dendritic spine development in hippocampal neurons. Journal of Neuroscience 28(41): 10339-10348.

Pallas, M., Camins, A., Smith, M.A., Perry, G., Lee, H.G. \& Casadesus, G. 2008. From aging to Alzheimer's disease: Unveiling "the switch" with the senescence-accelerated mouse model (SAMP8). Journal of Alzheimer's Disease 15(4): 615-624.

Patil, K.B. 2018. Progenitor Cells vs. Stem Cells: Differences in Roles and Functions. https://biologywise.com/progenitorcells-vs-stem-cells. Accessed on 20 August 2019.

Pueschel, S.M. \& Pueschel, J.K. 1992. Biomedical concerns in persons with down syndrome. Book Reviews 42(12): 222.

Rachubinski, A.L., Crowley, S.K., Sladek, Jr. J.R., Maclean, K.N. \& Bjugstad, K.B. 2012a. Effects of neonatal neural progenitor cell implantation on adult neuroanatomy and cognition in the Ts65Dn model of down syndrome. PLoS ONE 7(4): 1-13.

Rachubinski, A.L., Maclean, K.N., Evans, J.R. \& Bjugstad, K.B. 2012b. Modulating cognitive deficits and tau accumulation in a mouse model of aging down syndrome through neonatal implantation of neural progenitor cells. Experimental Gerontology 47(9): 723-733.

Reinholdt, L.G., Ding, Y., Gilbert, G.J., Gilbert, G.T., Czechanski, A. \& Solzak, J.P. 2011. Molecular characterization of the translocation breakpoints in the down syndrome mouse model Ts65Dn. Mammalian Genome 22(11-12): 685-691.

Roizen, N.J. 2005. Complementary and alternative therapies for Down syndrome. Mental Retardation and Developmental Disabilities Research Reviews 11(2): 149-155.

Roizen, N.J. \& Patterson, D. 2003. Down's syndrome. Lancet 361(9365): 1281-1289.

Sebastiá, J., Cristofol, R., Pertusa, M., Vilchez, D., Toran, N. \& Barambio, S. 2004. Down's syndrome astrocytes have greater antioxidant capacity than euploid astrocytes. European Journal of Neuroscience 20(9): 2355-2366.

Shen, S., Xia, J. \& Wang, J. 2016. Nanomedicine-mediated cancer stem cell therapy. Biomaterials. 74: 1-18.

Shichiri, M., Yoshida, Y., Ishida, N., Hagihara, Y., Iwahashi, H. \& Tamai, H. 2011. Alpha-tocopherol suppresses lipid peroxidation and behavioral and cognitive impairments in the ts $65 \mathrm{dn}$ mouse model of down syndrome. Free Radical Biology and Medicine 50(12): 1801-1811.

Shroff, G. 2016. Human embryonic stem cells in the treatment of patients with down syndrome: A case report. Journal of Medical Cases 7(4): 123-125.
Smith, G.K., Kesner, R.P. \& Korenberg, J.R. 2014. Dentate gyrus mediates cognitive function in the Ts65Dn/DnJ mouse model of down syndrome. Hippocampus 24(3): 354-362.

Tomobe, K. \& Nomura, Y. 2009. Neurochemistry, neuropathology, and heredity in SAMP8: A mouse model of senescence. Neurochemical Research 34(4): 660-669.

US National Library of Medicine. National Institutes of Health Search database. 2019. https://www.ncbi.nlm.nih. gov/pubmed. Accessed on 19 August 2019.

Van Dyke, D.C., Land, D.J., van Duyne, S., Heide, F. \& Chang, H. 1990. Cell therapy in children with down syndrome: A retrospective study. Pediatrics 85(1): 79-84.

Wiseman, F.K., Al-Janabi, T., Hardy, J., Karmiloff-Smith, A., Nizetic, D. \& Tybulewicz, V.L. 2015. A genetic cause of Alzheimer disease: Mechanistic insights from down syndrome. Nature Review Neuroscience 16(9): 564-574.

Yang, H., Wen, S.R., Zhang, G.W., Wang, T.G., Hu, F.X. \& Li, X.L. 2011. Effects of Chinese herbal medicine Fuzhisan on autologous neural stem cells in the brain of SAMP-8 mice. Experimental Gerontology 46(8): 628-636.

Zigman, W.B., Devenny, D.A., Krinsky-McHale, S.J., Jenkins, E.C., Urv, T.K. \& Wegiel, J. 2008. Alzheimer's disease in adults with down syndrome. International Review of Research in Mental Retardation 36: 103-145.

Zis, P. \& Strydom, A. 2018. Clinical aspects and biomarkers of Alzheimer's disease in down syndrome. Free Radical Biology and Medicine 114: 3-9.

Norizam Salamt, Ruszymah Haji Idrus \& Noor Wahidah Mohd Nasri*

Department of Physiology

Faculty of Medicine

Universiti Kebangsaan Malaysia Medical Centre

Bandar Tun Razak, 56000 Cheras, Kuala Lumpur Malaysia

Noor Wahidah Mohd Nasri*

Department of Nursing

Faculty of Medicine

Universiti Kebangsaan Malaysia Medical Centre

Bandar Tun Razak, 56000 Cheras, Kuala Lumpur

Malaysia

*Corresponding author; email: idanasri@ppukm.ukm.edu.my

Received: 22 October 2019

Accepted: 28 September 2020 